\title{
Detecção da mutação 470del20 no gene CHRNE responsável pela síndrome miastênica congênita em bovinos da raça Brahman no Brasil
}

Anelize S Trecenti, Danilo GA Andrade, André V Fernandes, Andreza Pimenta-Oliveira,Alexandre S Borges, José P Oliveira Filho"

Faculdade de Medicina Veterinária e Zootecnia, Universidade Estadual Paulista (Unesp), Botucatu, SP, Brasil

*Autor correspondente

e-mail: zefilho@fmvz.unesp.br

\section{Resumo}

A síndrome miastênica congênita (SMC) é uma enfermidade de caráter autossômico recessivo e foi descrita em bezerros da raça Brahman. Decorrente da deleção de 20 pares de bases no éxon 5 do gene receptor neuromuscular de acetilcolina (CHRNE), produz uma proteína afuncional. A enfermidade é caracterizada por fraqueza muscular progressiva em bezerros, a qual se acentua após exercício e melhora com o repouso. Com prognóstico ruim, os animais são submetidos à eutanásia nas primeiras semanas de vida. Embora a prevalência de heterozigotos já tenha sido descrita em outros países, e.g. África do Sul (0,97\% - 0,5 a 1,68\%), não há nenhum relato de estudo desta natureza no Brasil. Sendo assim, o objetivo desta pesquisa foi estimar a prevalência da mutação 470del20 no gene CHRNE em bovinos da raça Brahman no Brasil. Utilizou-se DNA de 264 bovinos da Raça Brahman, provenientes de propriedades localizadas em 12 estados brasileiros, em reações de PCR, que amplificavam a região que continha a mutação 470del20. Os produtos de PCR foram purificados e submetidos ao sequenciamento direto. As sequências e os eletroferogramas obtidos foram analisados para a obtenção dos genótipos dos animais. 0 alelo mutado foi detectado em heterozigose (N/ CHRNE) em dois animais (0,8\%, 2/264), sendo os demais (99,2\%; 262/264) homozigotos dominantes $(\mathrm{N} / \mathrm{N}$, Wild type). Animais homozigotos recessivos (afetados) não foram detectados devido à mortalidade precoce provocada pela SMC. Portanto a prevalência de animais carreadores no Brasil se assemelha à prevalência do rebanho sul-africano. A raça Brahman foi concebida nos EUA e reprodutores americanos formaram a base do rebanho Brahman em diversos países como Brasil e África do Sul. Embora os pedigrees dos animais do presente estudo não tenham sido analisados, sabe-se que dois touros americanos foram responsabilizados pela entrada deste gene alelo na África do Sul. Considerando o caráter recessivo da enfermidade e que a população esteja em equilíbrio, estima-se que no Brasil nasça um bezerro afetado a cada 70 mil nascimentos. Assim como ocorre na África do Sul, o número de nascimentos de animais afetados 
também é baixo, entretanto, o impacto da doença pode aumentar a medida que não se tenha o conhecimento dos animais heterozigotos utilizados de forma massiva na multiplicação da raça. Portanto, o controle dos acasalamentos com base no genótipo se faz importante para minimizar prejuízos econômicos, uma vez que a doença é letal em animais homozigotos recessivos.

Agradecimentos: à Associação Brasileira dos Criadores de Zebu pelo fornecimento das amostras, à Coordenação de Aperfeiçoamento de Pessoal de Nível Superior (Processo 23038.007227/2012-04) pelo financiamento da pesquisa, e ao Conselho Nacional de Desenvolvimento Científico e Tecnológico pela concessão de bolsa de mestrado. 